INIERNAT IONAL BULLETIN OF BACTERIOL OGICAL NOMENCLATURE AND TAXONOMY

Vol. 8, Nos. 3-4 Octaber 15, 1958 pp. 195-196

REQUEST FOR EMENDATION OF SECTION 6 OF OPINION 11

\author{
Preliminary Statement \\ W. H. Ewing \\ International Shigella Center (Atlanta), \\ Communicable Di sease Center, \\ At lanta, Georgia
}

1. Review of Action by the Judicial Commission.

The first sentence of Draft Proposal I (International Bulletin 3:83, 1953) was approved and reads as follows: "Shigella dysenteriae (Shiga), Castellani and Chalmers was validly published and is legitimate as the name of the dysentery bacterium described by Shiga (1898)" (ibid., 3: 150, 1953; 4: 148 , 1954 .

Draft proposals 2, 3, and 4 (ibid., 3:83-84, 1954) were approved (ibid., $3: 150,1953 ; 4: 149,1954$ ), by which action the specific epithets flexneri, boydii, and sonnei were conserved.

The first sentence of Draft Proposal 5 (ibid., $3: 84$, 1953) was amended to read: "A type or standard culture is to be designated by the Enterobacteriaceae Subcammittee of the International Nomenclature Committee for each of the four species" (ibid., 3:151, 1953; 4: 149, 1954).

A new Draft Proposal 6 was proposed by Dr. Murray and seconded by Dr. Cowan and was approved unanimously (ibid., 3: 151 , 1953). Proposal 6 reads as follows: "A culture beIonging to the species Shigella flexneri, Shigella boydi (or) Shigella sonnei could be completely identified by appending to the name "serotype ...." (ibid., 3:151, 1953; $4: 149,1954)$.

\title{
2. Comment.
}

By their approval of the first sentence of Draft Proposal 1 and by their approval of Draft Proposals 2, 3, 4, and 5 , the Judicial Commission recognized the existence of four species in the genus Shigella: Shigella dysenteriae, Shige lla flexneri, Shigella boydii, and Shigella sonnei. However, the Judicial Commission failed to act upon the remainde r of Draft Proposal 1 and did not publish an Opinion on the advisability 
of adding microorganisms as serotypes within Shigella dysenteriae, although the Commission allowed for this practice within the other three species by their approval of Draft Proposal 6 (Opinion 11, section 6).

Originally, the Shigella Commission of the Enterobacteriaceae Subcommittee recommended that serotypes wi thin all four species of Shigelia should be completely identified by adding the appropriate serotype number to the specific name. Arabic numerais, not names, were selected to designate the various serotypes within each of the four species or subgroups. This system of taxonomy and nomenclature was accepted by the Enterobacteriaceae Subcomittee and has been employed in the last three Subcomittee reports, i.e., those presented to the International Congresses in Rio de Janeiro (1950), Rome (1953), and Stockholm (1958). Since the system was first introduced in 1949, it has gained wide acceptance and now is used in most parts of the world.

\section{Recommendation.}

Since the system of taxonomy and nomenclature for the genus Shigella employed by the Enterobacteriaceae Subcommittee recognizes only one species (Shigella dysenteriae) within Shigella subgroup $A$ and allows for the designation of serotypes within this species by the use of Arabic numerals, it is recommended that Section 6 of Opinion 11 (Draft Proposal 6) be officially amended in accordance with current practice, in order to render the system of serotype designation uniform throughout the entire genus.

Therefore, it is recommended that the following emendation of Section 6, Opinion 11, be approved by the Judicial Commission:

\section{Draft Proposal 7 (File 54).}

A culture belonging to the species Shigella dysenteriae, Shigella flexneri, Shigella boydii, or Shigella sonnei may be completely identified by appending the appropriate serotype number (arabic) to the name. 